\title{
Use of Associated Chromatographic Techniques in Bio-Monitored Isolation of Bioactive Monoterpenoid Indole Alkaloids from Aspidosperma ramiflorum
}

\author{
Talita Perez Cantuaria Chierrito ${ }^{1}$, Ananda de Castro Cunha ${ }^{1}$, Luzia Koike², \\ Regina Aparecida Correia Gonçalves ${ }^{1}$ and Arildo José Braz de Oliveira ${ }^{1}$ \\ ${ }^{1}$ Department of Pharmacy, State University of Maringá, Maringá, Paraná State, \\ ${ }^{2}$ State University of Campinas, Chemistry Institute, Campinas-SP,
}

Brasil

\section{Introduction}

The genus Aspidosperma (Apocynaceae) have been commonly used in folk medicine as potential antimalarial agents; in the treatment of leishmaniasis; uterus and ovary inflammations; as a contraceptive; in diabetes; stomach disorders; against cancer; fever and rheumatism (Oliveira et al, 2009). It commonly grows in tropical America, extracted from trees ranging 2 to $60 \mathrm{~m}$ in height. It is found in a variety of habitats from the dry fields of south-central Brazil, Paraguay, and Argentina to the inundated river margins of the Amazon basin (Tanaka, 2006). The main constituents of the Aspidosperma genus are indole alkaloids, a class of substances with a wide range of pharmacological activities such as cholinesterase inhibitors, analgesic, anti-inflammatory, bactericidal, oestrogenic, stimulant and depressant of the central nervous system (CNS) (Zocoler et al, 2005).

\subsection{Chromatographic systems in Aspidosperma genus}

Several methods are available for the analysis and identification of known indole alkaloids. Analysis of complex mixtures is frequently done by means of Thyn Layer Chromatography (TLC), through comparison of Rf values obtained in different solvent systems, and also by comparison between specific color reactions of components of the mixture and reference compounds. TLC remains one of the preferred methods for qualitative analysis of known compounds since it requires neither sophisticated equipment nor extensive sample preparation. For quantitative analysis, High Performance Liquid Chromatography (HPLC) systems linked to a UV detector are commonly used. By coupling HPLC to a photodiode array UV detector makes it possible to combine the information over retention times and the UV spectrum of each compound, and in some cases, it also enables the quantification of overlapping peaks. Capillary Gas Chromatography (GC) analysis has been described for several classes of alkaloids. A major advantage of GC over the above-mentioned methods is its enhanced sensitivity and high resolution. Another advantage is its easy coupling to a 
mass spectrometer that allows the identification of new and minor compounds of a mixture without laborious isolation procedures, which makes it a particularly attractive method when no decomposition due to the high temperatures applied in GC occurs (Dagnino, 1991). This chapter shows different chromatographic techniques (TLC, Preparative Thyn Layer Chromatography (PTLC), Classical Liquid Column Chromatography (CLCC), GC and HPLC) to isolate and characterize indole alkaloids of Aspidosperma ramiflorum species.

\subsubsection{Aspidosperma ramiflorum species}

Aspidosperma ramiflorum Muell. Arg. species commonly known as "guatambu", had been studied in 1996 by Reis et al., who were able to isolate the monoterpenoid indole alkaloids, ramiflorine A (1), ramiflorine B (2), 10-methoxy-geissoschizol (3) and $\beta$-yohimbine (4). After that, Oliveira 1999 isolated beyond these compounds the 16-(E)-isositrikine (5), all them from stem barks (Figure 1).

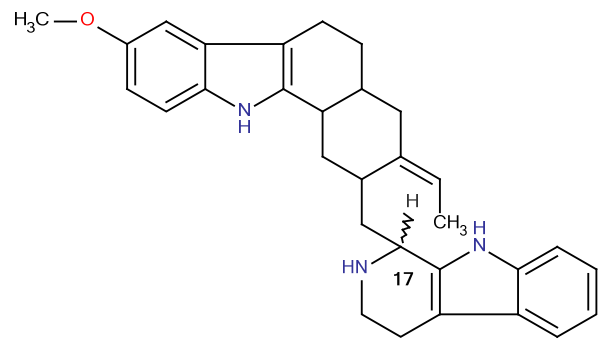

$\mathrm{H}-17-\alpha$ ramiflorine $\mathrm{A}(1)$ $\mathrm{H}-17-\beta$ ramiflorine $\mathrm{B}(2)$<smiles>C/C=C1/CC2CCc3c([nH]c4ccc(OC)cc34)C2CC1CCO</smiles>

10-methoxy-geissoschizol (3)<smiles>COC(=O)[C@H]1C2CC3c4[nH]c5ccccc5c4CCN3CC2CC[C@H]1O</smiles>

$\beta$-yohimbine (4)<smiles>C/C=C1/CC2CCc3c([nH]c4ccccc34)C2CC1[C@H](CO)C(=O)OC</smiles>

$(+/-)-16-(E)$-isositrikine (5)

Fig. 1. Major monoterpenoid indole alkaloids from Aspidosperma ramiflorum. Marvin was used for drawing, displaying and characterizing chemical structures, substructures and reactions, Marvin 5.4.1.1, 2011, ChemAxon available on ( http://www.chemaxon.com ).

The basic crude extract from stem barks of A. ramiflorum showed a good antileishmanial activity (Ferreira et al., 2004), which we attributed to the presence of indole alkaloids, and soon after, we described the fractionation, purification and isolation of alkaloids responsible 
for the activity against Leishmania (L.) amazonensis (Tanaka et al., 2007). Our results revealed that dimeric corynanthe alkaloids Ramiflorines A (1) and B (2) were responsible for the activity against promastigote forms of L. amazonensis with significant activity ( $\mathrm{LD}_{50}$ values of $16.3 \pm 1.6 \mu \mathrm{g} / \mathrm{ml}$ and $4.9 \pm 0.9 \mu \mathrm{g} / \mathrm{ml}$, respectively). Tanaka et.al. (2006) evaluated the antibacterial activities of the crude methanol extract, fractions obtained after acid-base extraction and pure compounds from the stem barks of Aspidosperma ramiflorum and both Ramiflorines showed significant activity against $S$. aureus (MIC $=25 \mu \mathrm{g} / \mathrm{mL}$ ) and E. faecalis $(\mathrm{MIC}=50 \mu \mathrm{g} / \mathrm{mL})$, with $\mathrm{EC}_{50}$ of 8 and $2.5 \mu \mathrm{g} / \mathrm{mL}$ for Ramiflorines $\mathrm{A}$ and $\mathrm{B}$, respectively, against $S$. aureus.

\section{General methods of alkaloids extraction}

From crude alcoholics or hidroalcoholics extracts obtained from parts of the plant material, two methods already described in the literature may be used for preliminary extraction of alkaloids; both methods take into account the basic nature of these compounds in order to concentrate them in pKas nearby and produce more purified fractions, preceding the phases of isolation and identification of substances. The first method consists of a complete acidbase partition (Figure 2), employing solvents such as chloroform or dichloromethane,

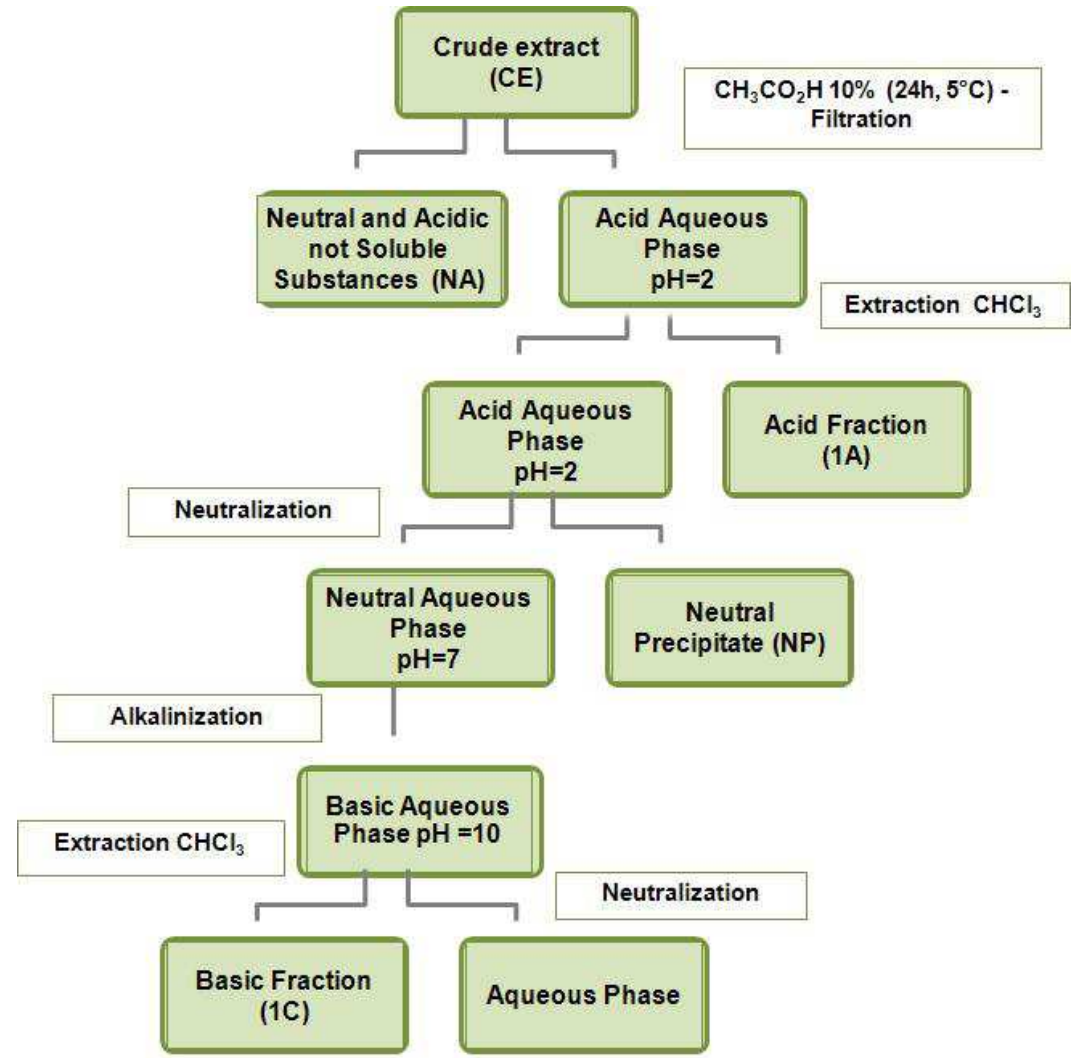

Fig. 2. Complete acid-base extraction from crude extract of A. ramiflorum. 
extracting alkaloids in three levels of $\mathrm{pH}$ (acid, neutral and basic) (Marques et al., 1996). In this extraction is possible to obtain four alkaloidal rich fractions: acidic fraction (1A), neutral precipitate fraction (NP), neutral fraction (1B) and basic fraction (1C). The second consists of a simplified acid-base partition (Figure 3), employing the same solvents, but with the absence of extraction at neutral $\mathrm{pH}$ in order to eliminate sample neutral substances, getting only two alkaloidal rich fractions: acidic fraction (1A) and basic fraction (1C) (Oliveira et al., 1999; Tanaka et al., 2007).

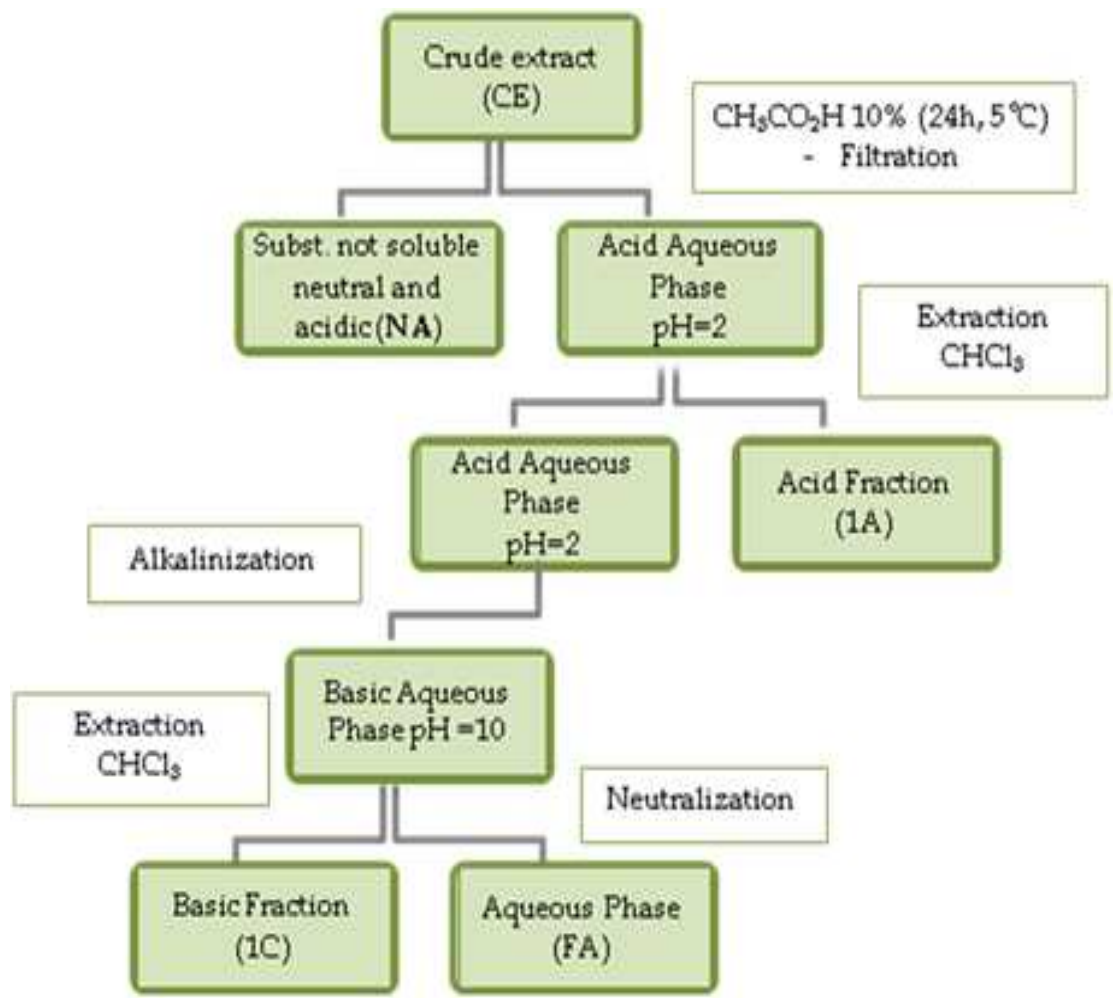

Fig. 3. Simplified acid-base extraction from crude extract of A. ramiflorum.

\section{Chromatographic analysis}

Chromatography is a physical-chemical method of separation and several are available for the analysis and identification of known indole alkaloids, the applicable to species $A$. ramiflorum are described below.

\subsection{Thin Layer Chromatographic - TLC}

\subsubsection{Analytical TLC}

As said before, analysis of complex mixtures is frequently done by TLC. It remains one of the preferred methods for qualitative analysis of known compounds since it requires neither 
sophisticated equipment nor extensive sample preparation (Dagnino et al., 1991). The analytical TLC contributes greatly to a preliminary characterization of the alkaloidal extract and fractions obtained from $A$. ramiflorum. Although the substances present in various parts of this species, ramiflorine A (1), ramiflorine B (2), 10-metoxy-geissoschizol (3), $\beta$-yohimbine (4), ( \pm )-16-(E)-Isositsirikine (5), they are already known and described (Marques, 1998; Marques et al, 1996; Oliveira, 1999; Ferreira et al., 2004), TLC plates at $R_{f}$ values of substances determined and revealed by UV light and specific reagents such as $p$-anisaldehyde and Dragendorff allow a prior identification of substances quickly and conclusively. Under UV light, substances with chromophore, i.e. conjugated systems absorb radiation and become fluorescent, since the stationary phase contains fluorescence indicator, the reactive $p$ anisaldehyde blush indole nucleus of purple and the reactive Dragendorff blush nitrogen compounds of orange. Figure 4 shows two TLC plates with samples of A. ramiflorum obtained by the team of Laboratory of Biotechnology of Synthetic and Natural Products of the State University of Maringá - PR, Brazil (LABIPROS), under the following conditions: stationary phase - commercial chromatoplate of aluminum in normal phase silica gel $60 \mathrm{~F}_{254}$ fluorescence indicator; mobile phase (S1) - chloroform, dichloromethane, ethyl acetate, methanol in the proportions of (4:1:4.5:0.5 v/v) in environment saturated with ammonia hydroxide; samples applied in strips by mini glass capillaries revealed with $p$-anisaldehyde and Dragendorff, respectively, confirming the presence of monoterpene indole alkaloids indólicos (MIA) in samples of the species A. ramiflorum through stains well demarcated and staining characteristics.
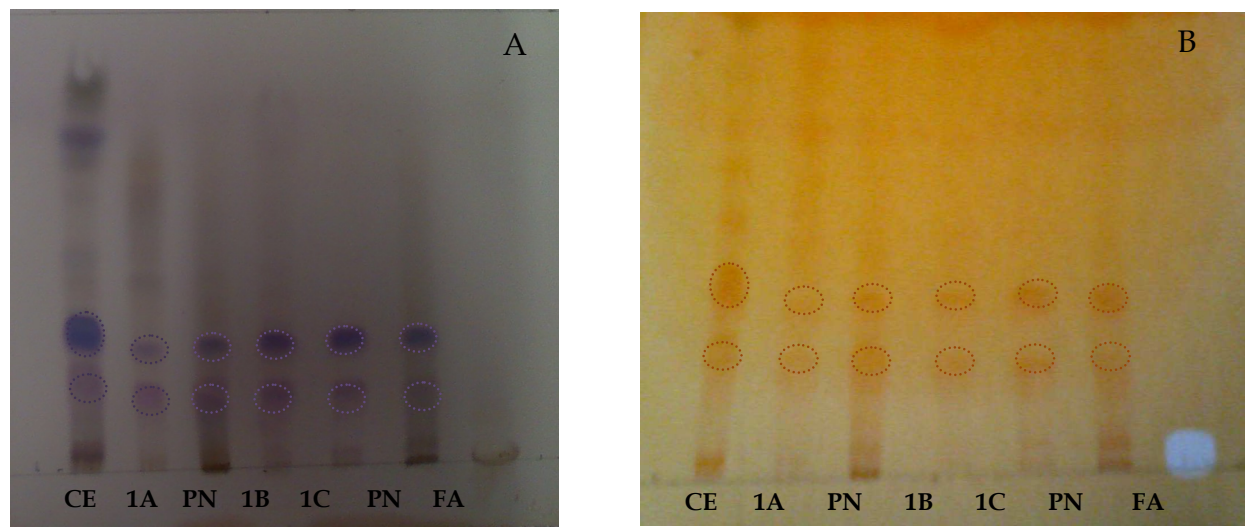

Fig. 4. A- Alkaloidal factions of A. ramiflorum revealed with $p$-anisaldehyde; B- Alkaloidal fractions of $A$. ramiflorum revealed with Dragendorff.

Variations on the combination of solvents and eluents generated changes in $R f$ values for the same substance, as exemplified in Table 1, in which the same substances subject to the eluent system 1 (S1) used by the team LABIPROS have $R f$ values distinct from the subject to the eluent system 2 (S2) used by Oliveira (1999). 


\begin{tabular}{|c|c|c|c|c|}
\hline \multicolumn{2}{|c|}{ Composition of Eluent Systems (v/v) } & $\begin{array}{l}\text { Stationary } \\
\text { Phase }\end{array}$ & $\begin{array}{c}\text { Substances } \\
\text { applied on TLC } \\
\text { plates }\end{array}$ & $\mathrm{R}_{f}$ values \\
\hline \multirow{3}{*}{ (S1) } & \multirow{3}{*}{$\begin{array}{l}\text { Chloroform,dichloromethane, } \\
\text { ethyl acetate, methanol in the } \\
\text { proportions of } 4.5: 4: 1.5: 0.5+ \\
\text { saturation with ammonia } \\
\text { hydroxide }\end{array}$} & \multirow{3}{*}{$\begin{array}{l}\text { Sílica Gel } 60 \\
\mathrm{~F}_{254}\end{array}$} & (1) & 0.45 \\
\hline & & & (2) & 0.32 \\
\hline & & & (3) & 0.22 \\
\hline \multirow{3}{*}{$(\mathrm{S} 2)$} & \multirow{3}{*}{$\begin{array}{l}\text { Chloroform, ethyl acetate, } \\
\text { methanol + saturation with } \\
\text { ammonia hydroxide }\end{array}$} & \multirow{3}{*}{$\begin{array}{l}\text { Sílica Gel } 60 \\
\mathrm{~F}_{254}\end{array}$} & (1) & 0.76 \\
\hline & & & (2) & 0.30 \\
\hline & & & (3) & 0.36 \\
\hline
\end{tabular}

Table 1. Variations of $R f$ values of the same substances spotted on TLC plates subject different systems of eluents.

\subsubsection{Preparative TLC - PTLC}

The difference between the PTLC and the TLC is that, while the last employed to separation, identification and determination, not allows the retrieval of the sample, the preparative chromatography is a purification process and allows the isolation of pure substances contained in a mixture. Although there are many techniques developed for the isolation of natural products, PTLC is pretty used, being considered a relatively simple and inexpensive technique for separation and purification of small quantities of substances intended for chemical and physical-chemical studies. Although the migration time and the removal of the bands of substances are not easy and efficient, the LABIPROS team isolated by means of PTLC, stem barks and leaves of A. ramiflorum the same substances already isolated by other teams using different techniques (Marques et al, 1996; Ferreira et al, 2004). Figure 5 shows a preparative board applied, eluted and reveled in UV light $254 \mathrm{~nm}$, one of alkaloidal fractions obtained from acid-base extraction of A. ramiflorum, composed of three main substances, of class MIA. The conditions employed in this technique were the same as described in the previous section for TLC, with the exception of the plates which were in size $20 \times 20 \mathrm{~cm}$ with $1.0 \mathrm{~mm}$ thickness of silica gel $60 \mathrm{~F}_{254}$, and the sample was apllied in continuous line, with the help of a cotton brush. Figure 6, presents the TLC made to monitor and confirms the isolation by PTLC, demonstrated by natural spots in each application.

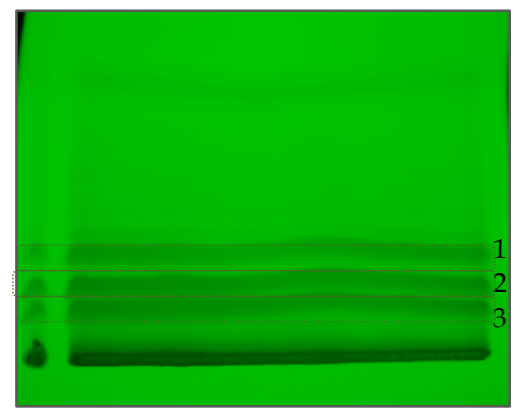

Fig. 5. PTLC alkaloidal fraction of A ramiflorum composed of three majority substances of class MIA, viewed by UV irradiation at $254 \mathrm{~nm}$. 


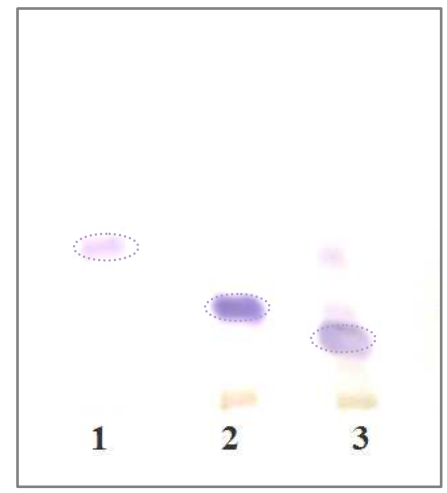

Fig. 6. TLC of the three major substances isolated by PTLC A. ramiflorum.

\subsection{Classical liquid column chromatography}

The majority of classical liquid column chromatography (CLCC) procedures for separating indole alkaloids from Aspidosperma use an adsorbent stationary phase as silicagel and the eluents employed reflect the polarity of alkaloids under investigation (Henrique et al., 2010; Barbosa et al., 2010). The majority of indole alkaloids are tertiary bases with fairly low polarity, so that mixtures containing a major part of a less polar solvent (e.g., chloroform, toluene) with a small proportion of more polar solvent (e.g., acetone, ethanol, methanol) are frequently cited (Henrique et al., 2010; Barbosa et al., 2010; Kobayashi et al., 2002). The use of technical variations of CLCC as flash, vacuum, low and medium pressure liquid chromatography has become common in the indole alkaloids isolation. Aspidosperma ramiflorum alkaloidal extract was also fractionated on a silica gel column, elutting with $\mathrm{CHC1}_{3}$ with increasing amounts of $\mathrm{MeOH}$ (Marques et al., 1996).

\subsection{Gas chromatography}

Capillary gas chromatography (GC) analysis has been described for several classes of alkaloids. The major advantage of GC over the above-mentioned methods is its enhanced sensitivity and high resolution. Another advantage, it is easy coupling to a mass spectrometer (Biemann, 2002) that allows the identification of new and minor compounds of a mixture without laborious isolation procedures, which makes it a particularly attractive method when no decomposition due to the high temperatures applied in GC occurs but the widespread application of this technique is limited by volatility of more polar alkaloids.

The number of articles describing capillary GC analysis of underivatized alkaloids is continuously increasing, including indole alkaloids (Dagnino et al., 1991; Gallagher et al., 1995; Cardoso et al., 1997; Cardoso et al., 1998, Zocoler et al., 2005). Based on some of these works we developed a simple, rapid, sensitive, and reproducible technique for the qualitative and quantitative analyses of Aspidosperma alkaloids by capillary GC. The analysis can be done because of a slightly polar and relatively short capillary column which we have used here, with $10 \mathrm{~m}$ long, which enabled a rapid analysis but with a good resolution of different components (Figure 7). Thus, we separated alkaloids representing different chemical skeleton types from A. pyricollum, A. olivaceum, A. pyrifolium, A. polyneuron and A. ramiflorum. Using capillary GC, we were able to achieve complete separations of the 


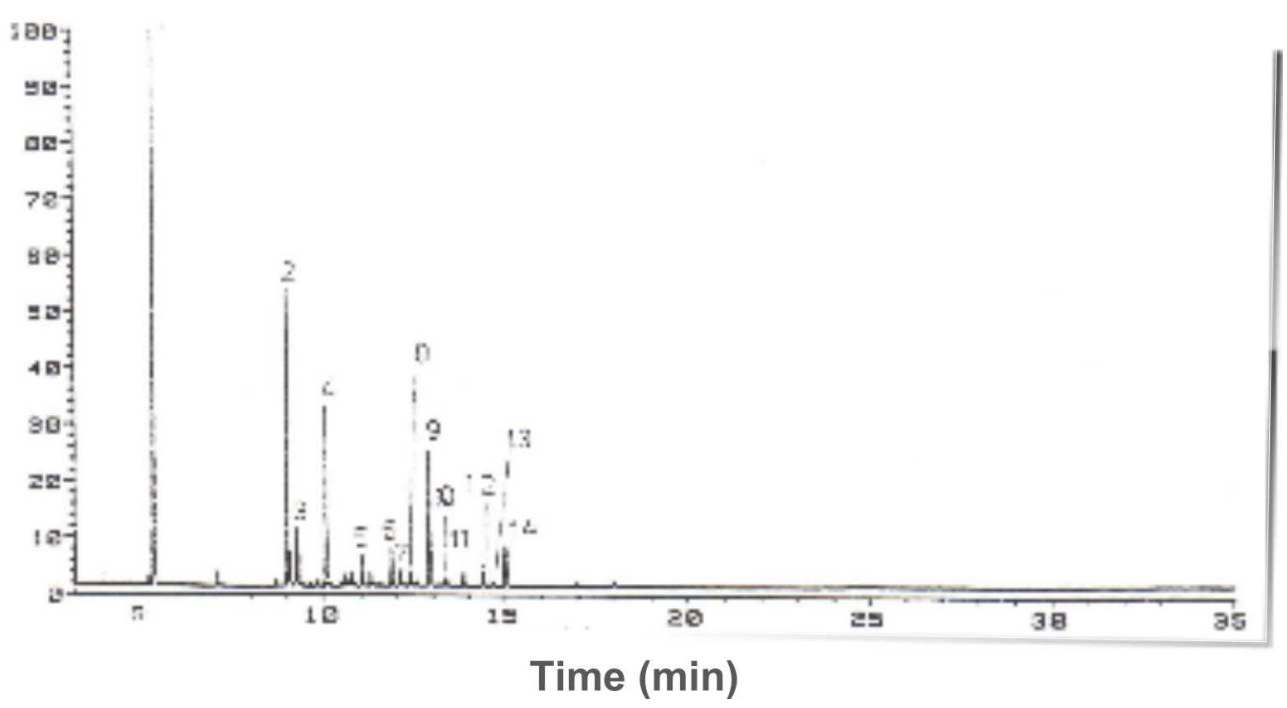

Fig. 7. GC-MS chromatogram of basic fraction (1C). Peaks - 1: internal standard (Tryptophol); 2: uleine; 3:Aspidofractine; 4: Apparicine; 5: 12-Demethoxy-aspidospermine; 6: Aspidospermine; 7: Olivacine; 8: 15-Demethoxy-pyrifoline; 9: Pyrifolidine; 10: 15-Methoxypyrifolidine; 11: Aspidofiline; 12: Pyrifolidine; 13: 15-Methoxy-pyrifolidine; 14: Aspidoscarpine (Oliveira , 1999).

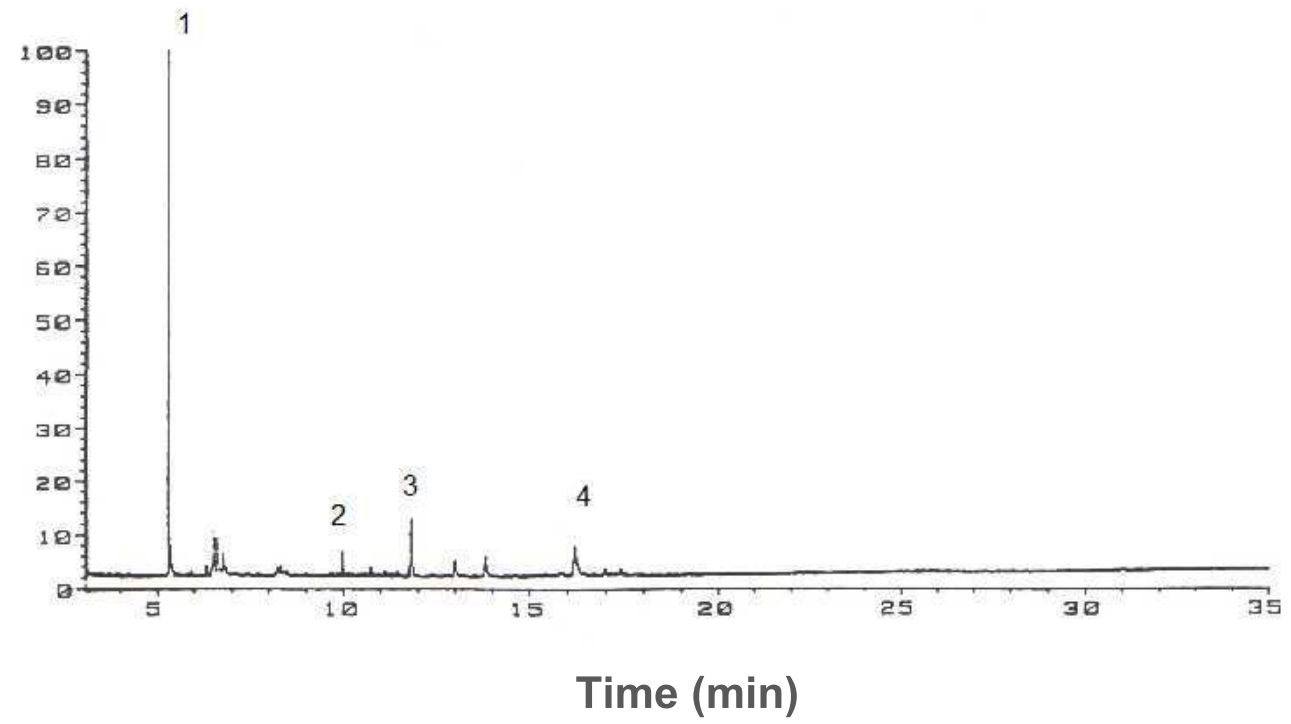

Fig. 8. GC-MS chromatogram of basic fraction (1C). Peaks - 1: internal standard (Tryptophol); 2: 1,2-Dihydro-olivacine; 3: Methoxy-1,2-dihydro-olivacine; 4: 10-Methoxygeissoschizol (Oliveira et al., 1999). 
compounds as example in the A. olivaceum analysis, Figure 7. The mass spectrum of each individual peaks was determined by GC-MS under identical conditions, and the expected molecular weight and fragmentation patterns were observed for all the compounds. For $A$. ramiflorum analysis by GC five indole alkaloids were isolated and characterized as follows: 10-methoxy-geissoschizol (3), (E)-isositsirikine (5), ramiflorine A(1) e ramiflorine B (2) from stem barks and $\beta$-yohimbine (4) from seeds, but only 10-methoxy-geissoschizol, (E)isositsirikine and $\beta$-yohimbine could be used as standards in GC analysis as shown in Figure 8. The compounds ramiflorine A and ramiflorine B are dimeric basic alkaloids, with high molecular weight and less volatile and they are therefore not analyzable under the used conditions. For this reason, we developed a HPLC analysis for A. ramiflorum alkaloids which is shown below.

\subsubsection{Gas chromatography analysis}

The stem barks of $A$. olivaceum and A ramiflorum were extracted on $\mathrm{EtOH}: \mathrm{H}_{2} \mathrm{O}(70: 30)$ and submitted an acid-basic extraction procedure in agreement with described in Figure 3 . The basic and acid chloroform extracts were weighted $(30 \mathrm{mg})$, which were diluted in $9 \mathrm{~mL}$ of a solution of $\mathrm{CH}_{2} \mathrm{Cl}_{2}: \mathrm{MeOH}(80: 20, \mathrm{v} / \mathrm{v})$. This mixture were homogenized and submitted to a filtration in a small column of silica-gel 60 Merck $(1 \mathrm{~g})$ and were eluted with a solution of $\mathrm{CH}_{2} \mathrm{Cl}_{2}: \mathrm{MeOH}(80: 20, \mathrm{v} / \mathrm{v})$. The filtrate was evaporated and the residue was dissolved in 2.5 $\mathrm{mL}$ of this solution and subsequently analyzed by GC or GC-MS. Standard compounds were obtained from Aspidosperma (Oliveira, 1999) using classic phytochemical extraction and separation methods and were identified by comparison of physical $\left(\mathrm{mp},[\mathrm{a}]_{\mathrm{D}}\right)$ and spectroscopy data (UV, ${ }^{1} \mathrm{H}$ and ${ }^{13} \mathrm{C} \mathrm{NMR}$ ) with literature values. The purity of the compounds was determined by gas chromatography using FID and MS detector. The GC analyses were done using a Hewlett-Packard 3396A gas chromatograph equipped with a FID. A DB- 5 capillary column $(12 \mathrm{~m}, 0.25 \mathrm{~mm}$ i.d. $x 0.2 \mathrm{~mm}$ film thickness, J \& W Scientific, CA) was used for this analysis. Hydrogen was utilized as the carrier gas, and the optimized oven temperature program was $100-225^{\circ} \mathrm{C}$, linear increase $15^{\circ} \mathrm{C} / \mathrm{min}$, after $225-260{ }^{\circ} \mathrm{C}$ in linear increase $2.5^{\circ} \mathrm{C} / \mathrm{min}$, and $260^{\circ} \mathrm{C}$ held for $10 \mathrm{~min}$. Temperatures of the injector port and detectors were held at $270{ }^{\circ} \mathrm{C}$. The injectors were operated in split mode (1:50). One microliter of all solutions was injected in all analysis. GC-MS analysis was carried out on HP 5970B gas chromatograph equipped with a MS detector. The temperature program was the same used for GC-FID analysis.

\subsection{High Performance Liquid Chromatography}

Despite the large number of Aspidosperma alkaloids isolated and their biological importance, there are very few reports on the HPLC analysis of extracts of species from this genus (Jacome et al., 2003; Jacome et. al., 2004). This can be explained due to HPLC that has been used in great extent to the analysis of different types of alkaloids, problems still exist, because analysis of this compound still occur with a low efficiency, large and asymmetric peaks, attributed to the dual retention mechanism (Philipson et al., 1982; Verpoorte \& Baherheim, 1984; Stockigt et al., 2002). For A. ramiflorum analysis by HPLC, the three majors indole alkaloids were isolated and characterized as follows: 10-methoxy-geissoschizol (3), ramiflorine $\mathrm{A}(\mathbf{1})$ and ramiflorine $\mathrm{B}$ (2) from stem bark and $\beta$-yohimbine (4) from seeds, which were used as standards in HPLC analysis, as shown in Figures 9A and B. To minimize the negative effects attributed to the dual retention mechanism, a methodology described by Giroud el al. (1991) to Chinchona legderiana was adapted to A. ramiflorum 
alkaloidal extract analysis, with some minor modifications, which allowed a good separation of it majority compounds (Figure 9B). The main modification made was the addition of octane sulfonic acid to mobile phase. The presence of this component allowed that the separation to be mediated by more types of interaction, because it acts by an ion pair formation mechanism, increasing the resolution and efficiency of analysis.

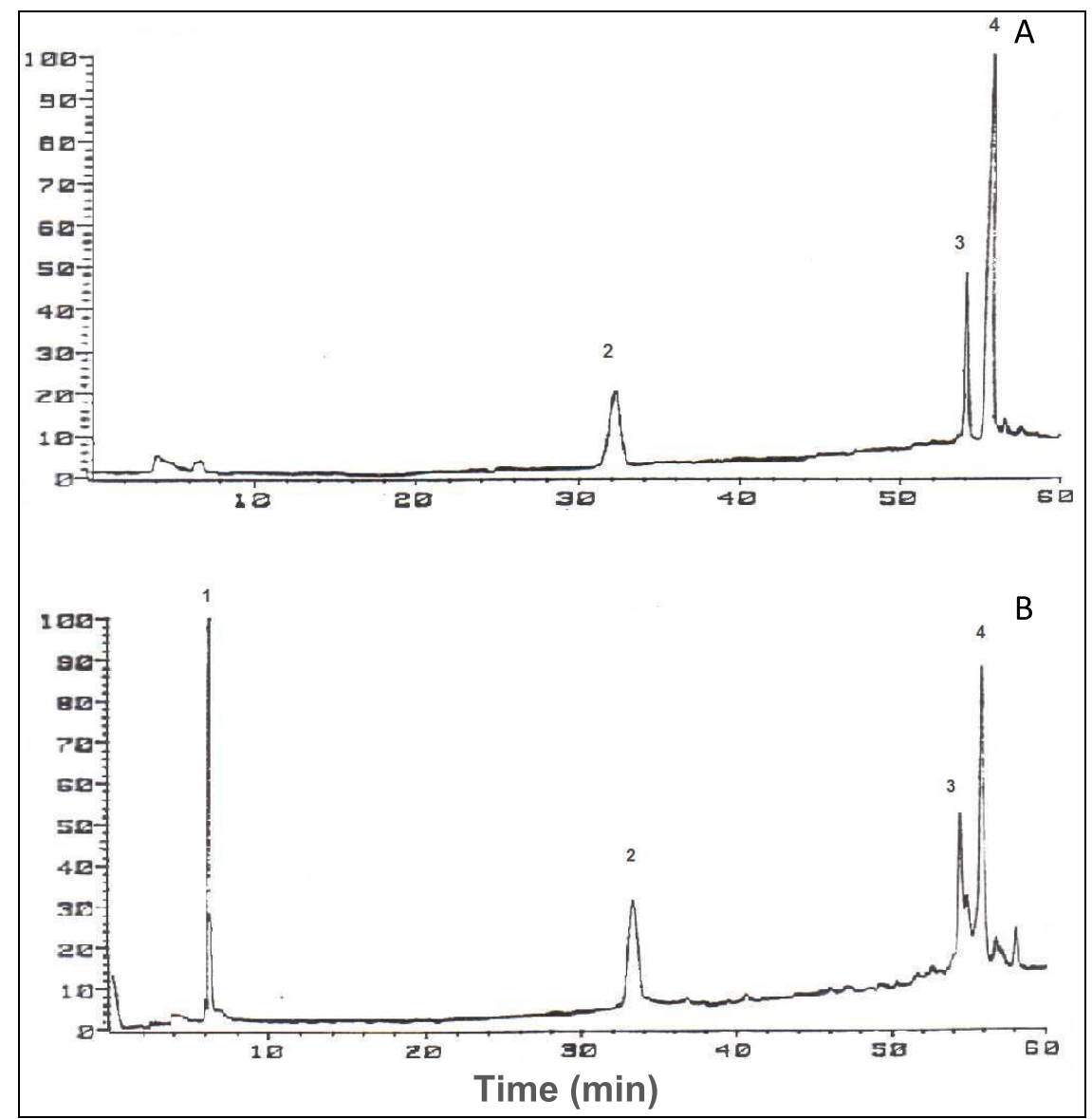

Fig. 9. A: high performance liquid chromatography (HPLC) chromatogram of standards mixture isolated from Aspidosperma ramiflorum; B: HPLC chromatogram of alkaloidal extract. Peaks - 1: internal standard (tryptophol); 2: 10-methoxy-geissoschizol; 3: ramiflorine A; 4: ramiflorine $\mathrm{B}$.

\subsubsection{High Performance Liquid Chromatography analysis}

For HPLC analysis, the crude extract of A ramiflorum (Ferreira et al., 2007) was dissolved in $\mathrm{CH}_{2} \mathrm{Cl}_{2}: \mathrm{MeOH}(80: 20 \mathrm{v} / \mathrm{v})$ and $10 \mu \mathrm{L}$ were injected into a Waters $\mu$-Bondapak RP-18 (reverse phase, $4.6 \mathrm{~mm} \times 250 \mathrm{~mm}$ ) column at $40^{\circ} \mathrm{C}$. Solvent A was $100 \mathrm{mmol} / \mathrm{L}$ ammonium formate in $0.12 \%$ octane sulfonic acid $(\mathrm{v} / \mathrm{v})$, formic acid and acetonitrile $(88: 4: 8, \mathrm{v} / \mathrm{v})$, while solvent $B$ 
consisted of $100 \mathrm{mmol} \backslash \mathrm{L}$ aqueous ammonium formate containing $0.12 \%$ octanesulfonic acid $(\mathrm{v} / \mathrm{v}) /$ formic acid/acetonitrile (64:4:32, v/v). The separation was carried out using a mixture of solvent $A$ and, a progressively increasing amount of $B(0,10,40,90,100 \%)$ during $60 \mathrm{~min}$. The flow rate was $1.3 \mathrm{ml}$ min-1. The effluent was monitored with a photodiodearray detector with windows at $222 \mathrm{~nm}$ and $254 \mathrm{~nm}$ and also by mass spectral analysis of isolated eluates.

\section{Conclusions}

The development of the TLC solvent system for Aspidosperma ramiflorum alkaloids at the beginning of this article clearly shows that TLC and PTLC as a routine and classical method appreciated in alkaloid separation techniques, can still be optimized with introduction of new methodologies as desorption electrospray ionization (DESI) which can permit coupled TLC with mass spectrometry (Jackson et al., 2009). This is not necessarily true for alkaloid determination by GC, because decomposition can occur due to the high temperatures applied and however widespread application of this technique is limited by volatility of more polar alkaloids. HPLC is a classical method for alkaloids separations and allowed a good separation of majority compounds in A. ramiflorum alkaloids but can still be optimized. However, the pre-purification of crude alkaloid extract will be a crucial step for all analytical procedure described. The applicability of different chromatographic techniques for the separation and identification of crude mixtures of bioactive A. ramiflorum indole alkaloids has thus been demonstrated.

\section{References}

Barbosa, L. F.; Mathias, L.; Braz-Filho, R. \& Vieira, I. J. C., (2010). Chemical constituents from Aspidosperma illustre (Apocynaceae). J. Braz. Chem. Soc., 21, 1434-1438.

Biemann, K., (2002). Four Decades of Structure Determination by Mass Spectrometry: From Alkaloids to Heparin. J Am Soc Mass Spectrom, 13, 1254-1272.

Cardoso, C. A. L.; Vilegas, W. \& Honda, N. H. (1998).Qualitative determination of indole alkaloids, triterpenoids and steroids of Tabernaemontana hilariana J. Chromatogr., A. $808,264$.

Cardoso, C. A. L.; Vilegas, W. \& Pozetti, G. L. (1997).Gas chromatographic analysis of indole alkaloids from Tabernaemontana hilariana. J. Chromatogr.,A, 788, 204.

Dagnino, D., J. Schripsema, A. Peltenburg, R. Verpoorte \& K. Teunis. (1991). Capillary gas chromatographic analysis of indole alkaloids: investigation of the indole alkaloids present in Tabernaemontana divaricata cell suspension culture. J. Nat. Prod. 54:15581563.

Ferreira, I., Leon, L., Gobbi Filho, L., Lonardoni, M., Silveira, T., Machado, G. \& Oliveira, A., (2004). Antileishmanial activity of alkaloidal extract from Aspidosperma ramiflorum. Mem. Inst. Oswaldo Cruz. Vol. 99, pp. 325-327.

Gallagher C. A.; Hough L. B.; Keefner S. M.,; Seyed-Mozaffari A.; Archer S.; \& Glick S. D., (1995). Biochemical Pharmacology, Vol. 49, No. 1, pp. 73-79.

Giroud, C.; Vanderleer, T.; Vanderheijden, R.; Verpoorte, R.; Heeremans, C. E. M.; Niessen, W. M. A. \& vandergreef, J. (1991). Thermospray liquid-chromatography massspectrometry (TSP LC MS) analysis of the alkaloids from Cinchona in vitro cultures. Planta Medica, 57, 142-148. 
Henrique, M. C.; Nunomura, S. M. \& Pohlit, A. M. (2010). Alcaloides indólicos de cascas de Aspidosperma vargasii e A. desmanthum. Química Nova, 33, 284-287.

Jackson, A. U., Tata, A., Wu, C., Perry, R. H., Haas, G., West, L., \& Cooks, R. G. (2009). Direct analysis of Stevia leaves for diterpene glycosides by desorption electrospray ionization mass spectrometry. Analyst, 134, 867-874.

Jácome, R. L. R. P.; Oliveira, A. B.; Raslan, D. S. \& Wagner, H. (2004).Estudo químico e perfil cromatográfico das cascas de Aspidosperma parvifolium A. DC. ("Pereira"). Quim. Nova, Vol. 27, No. 6, 897-900.

Jácome, R. L. R. P.; Souza, R. \& Oliveira, A.B. (2003).Comparação cromatográfica entre o extrato de Aspidosperma parvifolium e o fitoterápico "Pau-Pereira". Rev. Bras. Farmacogn., v. 13, supl., p. 39-41, 2003. ISSN: 0102-695X

Kobayashi, J; Sekiguchi, M.; Shimamoto, S.; Shigemori, H.; Ishiyama, H. \& Ohsaki, A., (2002). Subincanadines A-C, Novel Quaternary Indole Alkaloids from Aspidosperma subincanum. J. Org. Chem., 67, 6449-6455.

Marques, M., Kato, L., Filho, H. \& Reis, F., (1996). Indole alkaloid from Aspidosperma ramiflorum. Phytochemistry, v. 41, n. 3, pp.963-967.

Oliveira, A., (1999). Estudo de seis espécies do gênero Aspidosperma, utilizando CG, CG/MS e HPLC: Análise Qualitativa e Quantitativa. Teste Bioautográfico; Cultura de Tecidos e Células Vegetais e rota de Preparação dos Compostos Diméricos Ramiflorina A e Ramiflorina B. Universidade de Campinas, Campinas. Tese (doutorado em química orgânica).

Oliveira, V. B.; Freitas, M. S. M.; Mathias, L.; Braz-Filho, R. \&Vieira, I. J. C.; (2009).Atividade biológica e alcalóides indólicos do gênero Aspidosperma (Apocynaceae): uma revisão.Rev. Bras. Pl. Med., 11, 92.

Phillipson, J. D.; Supavita, N. \& Anderson, L. A. (1982). Separation of heteroyohimbine and oxindole alkaloids by reversed-phase high-performance liquid chromatography. Journal of Chromatography A, 244, 91-98.

Stockigt, J.; Sheludko, Y.; Unger, M.; Gerasimenko, I.; Warzecha, H. \& Stockigt, D., (2002). High-performance liquid chromatographic, capillary electrophoretic and capillary electrophoretic-electrospray ionisation mass spectrometric analysis of selected alkaloid groups. Journal of Chromatography A, 967, 85-113.

Tanaka J.C., Silva C.C., Ferreira I.C.P., Machado G.M.C., Leon L.L. \& Oliveira A.J.B., (2007). Antileishmanial activity of indole alkaloids from Aspidosperma ramiflorum. Phytomedicine 14, 377-380.

Tanaka JCA, Silva C.C., Dias F., B.P., Nakamura C.V. \& Oliveira A.J.B. (2006). Antibacterial activity of indole alkaloids from Aspidosperma ramiflorum. Braz J MedBiol Res 39: 387391.

Verpoorte, R. \& Baherheim, A. S. (1984).Chromatography of Alkaloids. Amsterdam, Netherlands, Elselvier, vol. 23B, p.31.

Zocoler, M.A., Oliveira, A.J.B., Sarragiotto, M.H., Grzesiuk, V.L. \& Vidotti, G.J., (2005). Qualitative determination of indole alkaloids of Tabernaemontana fuchsiaefolia (Apocynaceae). J. Braz. Chem. Soc. 16, 1372-1377. 


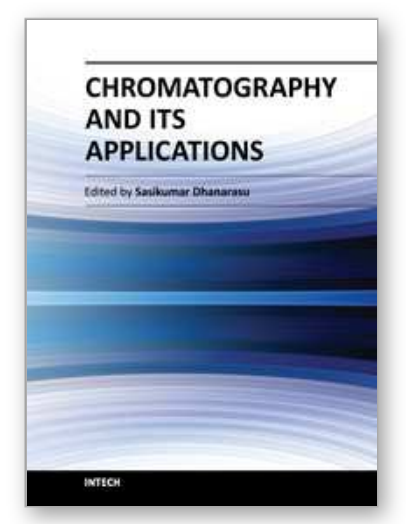

\author{
Chromatography and Its Applications \\ Edited by Dr. Sasikumar Dhanarasu
}

ISBN 978-953-51-0357-8

Hard cover, 224 pages

Publisher InTech

Published online 16, March, 2012

Published in print edition March, 2012

Chromatography is a powerful separation tool that is used in all branches of science, and is often the only means of separating components from complex mixtures. The Russian botanist Mikhail Tswett coined the term chromatography in 1906. The first analytical use of chromatography was described by James and Martin in 1952 , for the use of gas chromatography for the analysis of fatty acid mixtures. A wide range of chromatographic procedures makes use of differences in size, binding affinities, charge, and other properties. Many types of chromatography have been developed. These include Column chromatography, High performance liquid chromatography (HPLC), Gas chromatography, Size exclusion chromatography, Ion exchange chromatography etc. In this book contains more details about the applications of chromatography by various research findings. Each and every topics of this book have included lists of references at the end to provide students and researchers with starting points for independent chromatography explorations. I welcome comments, criticisms, and suggestions from students, faculty and researchers.

\title{
How to reference
}

In order to correctly reference this scholarly work, feel free to copy and paste the following:

Talita Perez Cantuaria Chierrito, Ananda de Castro Cunha, Luzia Koike, Regina Aparecida Correia Gonçalves and Arildo José Braz de Oliveira (2012). Use of Associated Chromatographic Techniques in Bio-Monitored Isolation of Bioactive Monoterpenoid Indole Alkaloids from Aspidosperma ramiflorum, Chromatography and Its Applications, Dr. Sasikumar Dhanarasu (Ed.), ISBN: 978-953-51-0357-8, InTech, Available from: http://www.intechopen.com/books/chromatography-and-its-applications/use-of-associated-chromatographictechniques-in-bio-monitored-isolation-of-bioactive-monoterpenoid-i

\section{INTECH}

open science | open minds

\author{
InTech Europe \\ University Campus STeP Ri \\ Slavka Krautzeka 83/A \\ 51000 Rijeka, Croatia \\ Phone: +385 (51) 770447 \\ Fax: +385 (51) 686166 \\ www.intechopen.com
}

\author{
InTech China \\ Unit 405, Office Block, Hotel Equatorial Shanghai \\ No.65, Yan An Road (West), Shanghai, 200040, China \\ 中国上海市延安西路65号上海国际贵都大饭店办公楼405单元 \\ Phone: +86-21-62489820 \\ Fax: $+86-21-62489821$
}


(C) 2012 The Author(s). Licensee IntechOpen. This is an open access article distributed under the terms of the Creative Commons Attribution 3.0 License, which permits unrestricted use, distribution, and reproduction in any medium, provided the original work is properly cited. 